\title{
Different Ways of Practicing Afro-Brazilian Religions in a Transnational Context: Germany
}

\author{
Joana Bahia (iD) https://orcid.org/0000-0002-2172-5022 \\ Department of Human Sciences \\ State University of Rio de Janeiro \\ joana.bahia@gmail.com
}

\begin{abstract}
In this text, I study Afro-Brazilian religions (Candomblé and Umbanda) and the ways these adapt themselves culturally in the German context, producing hybridisms and reviving European pagan practices. In the first section of the text, I present how pais and mães de santo circulate through the artistic field, creating opportunities for them to construct ritual spaces in which religious practices are conducted and future adepts are recruited. I then analyse cases in which pais de santo do not participate in this artistic field, or even have their own terreiros or initiate filhos de santo. Finally, I consider ritual adaptations and the ways of relating to the economic and spiritual necessities of potential clients. In these cases, Afro-Brazilian religions end up being in close proximity to New Age practices currently common in European cultures.
\end{abstract}

Keywords: Afro-Brazilian religions transnationalization, African diaspora, hybridism, Europe

Słowa kluczowe: afro-brazylijskie religie, transnacjonalizacja, afrykańska diaspora, hybrydyzm, Europa

\section{Introduction}

The first part of the present article analyzes Afro-Brazilian religions (Candomblé and Umbanda); ${ }^{1}$ the ways they culturally adapt in German contexts, producing

${ }^{1}$ I approach Candomblé in this article as the religion of the orishas (African gods) - in short, the religion constituted in the nineteenth century in the Brazilian state Bahia, drawing upon the Yoruba tradition. It was influenced by the habits brought over by Fon groups (called jejes in Brazil) and by African minority groups who were brought by the Portuguese as slaves to Brazil. Candomblé is divided into nations. Since the beginning, Yoruba Candomblé and other jeje-nagô traditions have brought together cultural aspects from different Yoruba cities, from which originate various rites or Candomblé nations. In 
hybridisms; the adaptations and difficulties of transnationalization they encounter; and the ways in which they revive European pagan practices. Here, I present the case that pais and mães de santo expand their religious practices into musical and bodily practices reproduced in workshops, cultural spectacles, theaters, and in the streets. They also promote religious expansion by transforming cultural spaces into terreiros. This is the case of the Forum Brasil in Berlin. In the second part, I analyse some cases in which pais de santo do not have terreiros, nor a presence in the artistic field, but expand the religion through their own mobility, which it is not circumscribed by the limits of Germany. These adapt the religion's language to the reality of their clients, creating new meanings in the face of different religious practices. These same mediators circulate their practices and objects among their clients, and are also influenced in the sense that they incorporate new religious practices into their daily lives.

During my field work from 2010 on, I have witnessed several different situations. I have undertaken multi-sited ethnography ${ }^{2}$ beginning in 2010, encompassing the physical and virtual mobility of social actors, objects, and signs, including the study of discourses and processes of relocation from Brazil to Europe. I attended dance performances and workshops held in the Berlin terreiro, an exhibition about orixás ${ }^{3}$ at Berlin City Hall during an Afro-culture month in which Brazil was selected as a focus, and the Afoxé Loni $^{4}$ parade during the Carnival

each nation, the traditions of the city or the region which gives the nation its name predominate: queto, ijexá and efã. This concept of nation lost its original ethnic meaning and has become more political than theological over the years (S. Capone, A Busca da Africa no Candomblé. Tradição e Poder no Brasil, Rio de Janeiro 2009). Today's nations are the ketu, ijexá, efon, angola, congo and caboclo. Thus, even if I adopt the term 'Afro-Brazilian religion' or speak of Candombé as a religion, like my interlocutors do, it refers to a very heterogeneous reality and a diversity of practices. The term 'Afro-Brazilian' is associated with the idea of legitimating Africa as the place of birth of this religious tradition and with establishing the tradition as a symbol of black resistance to slavery. Umbanda is a Brazilian religion based upon the notion of possession by the spirits. Created in the beginning of the twentieth century in Rio de Janeiro, it blends African religions with Catholicism, Spiritism (Allan Kardec), and considerable indigenous lore. In Umbanda, one worships and incorporates spirits (not gods). These are: exus, pombagiras,caboclos, Peoples of the East, Old Blacks, Cowboys, Seamen, and Bahians. Although the orixás (African gods) command the seven lines of the spiritual types, they are sometimes incorporated into them as well. This depends upon each different terreiro (temple) and the manners in which they relate to possession. (J. Bahia, Umbanda, [in:] Encyclopedia of Latin American Religions, H. Gooren (ed.), [in print]).

${ }^{2}$ G. Marcus, Ethnography in/of the World System. The Emergence of Multisited Ethnography, "The Annual Review of Anthropology" 1995, no. 24, pp. 95-117.

${ }^{3}$ Orixás are African gods venerated in Candomblé as mediators between Olorun (the supreme god) and mankind. In Candomblé and Umbanda, orixás and spirits are treated differently. People who worship Umbanda spirits do not require an initiation process as in Candomblé, and can be baptized and partake in confirmation rituals. Many of the followers of Candomblé cultivate their gods and prepare celebrations for them, because these gods are part of their life history.

${ }^{4}$ Afoxés are cultural-artistic groups based on Afro-Brazilian religious doctrines (E. Souza, Ekodidé. Relações de Gênero no Contexto dos Afoxés de Culto Nagô no Recife, Masters Dissertation, Post-graduate Program in Anthropology, Federal University of Pernambuco, Recife 2010, p. 8). In their relationship with the temples, the Afoxé groups pay homage to orixás who are their guides. They also receive religious care from Babalorixás and/or Yalorixás (the highest rank of Candomblé priests: he or she who takes care of the orixás). Murah's Afoxé Loni group was active in the Carnaval of Cultures for 14 years, but had to interrupt participation a few years back due to lack of funding from the city of Berlin. The group is composed of Brazilians, Germans, and Africans, totaling three hundred members who wear white 
of Cultures. ${ }^{5}$ I also consider the importance of the music and dance and the way artistic performances are used by the Ilê Obá Silekê Candomblé temple in Berlin in its process of religious transnationalization in Germany. Dance, workshops, and theatre are used by the pai de santo as a way to disseminate religion within the transnational context, playing a central role in the transnationalization of Candomblé among people of African descent and, increasingly, among white Europeans as well. ${ }^{6}$ I analyse Brazilian mobility and, through this, come to understand not only the German context but also contexts extending beyond this.

I also met other pais and mães de santos of Candomblé and Umbanda: Brazilians, Germans, and Austrians - with and without temples - in cities like Berlin, Hamburg, Stuttgart, Ulm, Mainz, and Munich. I also investigated Mother Habiba's temple (Verein), which spread the religion not only in Germany (Berlin, Graz, Bern), but also in Switzerland (St. Gallen) and Austria (Vienna). ${ }^{7}$ I mainly analyse Brazilian migrants who brought Candomblé and Umbanda to the country, looking at how they organise and expand these religions in multiple directions. I begin by analysing the Ilê Obá Sileke terreiro, located in Berlin. ${ }^{8}$ I discuss how the terreiro has been chosen as a case study in order to show how dance and music are fundamental elements in the expansion of these religions. I then analyse other modes of expansion of the religion, particularly the practices of Umbanda, which has spread beyond Germany while incorporating many new elements into its religious traditions. In some cases, I use as an example Umbanda terreiros administrated by Germans and Austrians, especially

(the central color in Candomblé) and yellow (a color related to Oxum, the African god of fresh waters, fertility, and beauty, who is of central importance during the Afoxé performances). Murah do not have the Afoxé anymore, because the mantainence of it was quite expensive and the local government never helped them with it.

${ }^{5}$ The Carnival of Cultures was created in 1996 by Werkstatt der Kulturen (WdK) in the neighborhood of Neukölln, Berlin. It is one of the biggest cultural events in Berlin. Carnivals are an opportunity to give visibility to the social aspects and values that comprise the basis of African culture in Brazil, and the Afoxés are part of this. Particular reference is made to music, dance, vocabulary, symbols, gestures, clothing and other elements that circumscribe these groups, making them a representation of street Candomble - the religious practice represented in an artistic performance on the street.

${ }^{6}$ J. Bahia, Dancing with the Orixás. Music, Body and the Circulation of African Candomble Symbols in Germany, "African Diaspora" 2016, no. 9, pp. 15-38.

${ }^{7}$ Eadem, As Religiões Afro-brasileiras em Terras Alemãs e Suiças, http://www.ics.ul.pt/publicacoes/ workingpapers/wp2013/wp2013_1.pdf [access: 17.01.2019]; eadem, Under the Berlin Sky. Candomblé on German shores, "Vibrant. Virtual Brazilian Anthropology" 2014, vol. 11, no. 2, pp. 327-370, eadem, Dancing with the Orixás..., op. cit.

${ }^{8}$ The Brazil Forum is a company, registered under German law and directed towards cultural activities related to Brazil, especially ones that value black culture. In order to establish the company, its headquarters, and the activities of the terreiro, Murah studied cultural management. The Brazil Forum is a respected institution in the city and cannot be separated from the role of Candomble in Germany, and nor from a more general strategy to expand the religion throughout Europe. In his culture management course, Murah learned how to represent Brazil, situating aspects of Brazilian culture as things that could be marketed by a company. The presence of activities that highlight the importance of music, dance, and the arts and the several ways in which a body can be used (such as in capoeira), place emphasis on elements that delimit the idea of Brazil as mainly black in the Forum. The temple is open every day, but most of the rituals are closed to the public and take place when there are no other activities at the cultural forum. There is a schedule of festivities and rituals, some of which are public while others are private. 
in order to deal with the uses of language in ritual and in material produced in books and CDs which may or may not be translated during the course of the transnationalization of religion.

Although there are pais de santo and mães de santo (fathers and mothers of saints) and various practitioners without terreiros or temples, or who have ties to casa de santos (saints' houses) in Brazil, or whose saints' families ${ }^{9}$ are spread across Europe, there are currently two Candomblé ilês (temples) registered in Germany and these religious practices are found throughout that country. One of the saints' temples can be found in a shop called Casa de Oxum, whose owner was a mãe de santo named Mutter Dalva. ${ }^{10}$ She had worked for 20 years at a Lebensberatung (a kind of counselor officially recognised by German laws), her own store that sold religious products now is closed. ${ }^{11}$ The other terreiro functions as a cultural forum and also as an Afropolitik ${ }^{12}$

${ }_{9}$ Religious kindship within the group. Complex ritual genealogies link the initiate to different terreiros (temples) of the same axé (a religious tradition transmitted via spiritual kinship and also a spiritual force concentrated in objects and people).

${ }^{10}$ Born in 1945 in the village of Capanema, Vilaguaí, in the municipality of Maragogipe in the state of Bahia, Dalva arrived in Germany in 1979. She came to the country to get married and worked cleaning houses until the fall of the Berlin Wall in November 1989. In 2009 she had been living for in Germany for 30 years. Her story is replete with references to Germany, the Berlin Wall, and Europe. For Dalva, the Mauer is a cemetery, a place for the eguns (the spirits of the dead) and offerings for Exu, because thousands of people died trying to cross it and because Berlin "belongs" to this orixá (J. Bahia, Under the Berlin Sky..., op. cit.; eadem, E o Preto Velho Fala Alemão. Espiritos Transnacionais e o Campo Religioso na Alemanha, "Revista del Cesla" 2015, no. 18, pp. 181-212). Exu is an African god in Candomblé, mediating between other gods and human beings. He is the comunicator between worlds. In Umbanda, he is a disencarnated spirit. In this sense, then, Berlin is a crossroads for different thoughts and cultures, being extremely cosmopolitan, and decisively marking Dalva's relationship with this orixá. This history of Berlin's famous wall is shot through with the spirits who died around it or crossing it. This transforms the Wall into a cemetery and a place for eguns, in turn making it a place that Mutter Dalva considers appropriate for offers to Exu, who is the lord of corners and crossroads. Exu is a mediator, a communicator between worlds, and also a trickster. Berlin is also, in this sense, a "trickster city," as demonstrated by its ability to deal with different cultures in contradictory ways. This makes it a special place, being in the eyes of its foreign inhabitants a city that does not represent Germany. "Berliner" is a term used to label not only those who were born and bred in the city, but also those foreigners that call the place home. These consider themselves to be Berliners but not Germans, because they belong to a city that embodies liberty and admixture (not necessarily pacific) between different types of people and cultures. To live in Berlin is, for many migrants, an apprenticeship in the migratory process, as they must learn to be tricksters. This is especially true since the fall of the Berlin Wall, as the differences created by the great flow of people(s) through the city have inflamed tempers and uncovered racism in the city (J. Behrends, Fremde und Fremd-Sein in der DDR. Zu historischen Ursachen der Fremdenfeindlichkeit in Ostdeutschland, Berlin 2003; J. Bahia, Under the Berlin Sky..., op. cit.).

11 J. Bahia, Under the Berlin Sky..., op. cit.

${ }^{12}$ Afropolitik is a political project of the Brazil Forum in which blacks between 18 and 35 are engaged in social projects that value the different black cultures that circulate in Berlin's urban milieu. Most of the participants were born in Germany, being the children of several different migratory flows. These Afrodeustch are not considered to be Germans in a society whose terms of nationality are based upon whiteness. For more on the theme, see: R. Brubaker, Citizenship and Nationhood in France and Germany, New York 1990; D. Nagl, Grenzfälle: Staatangehörigkeit, Rassismus und nationale Identität unter deustcher Kolonialherrschaft, Frankfurt a.M. 2007; M. Lidola, Appropriating the "Brasilienerin". Negociating Belonging and Unbelonging in Everyday Practice in Berlin, "Zeitschrift für Ethnologie" 2011, no 136, pp. 379-400; J. Bahia, Under the Berlin Sky ..., op. cit. 
project incorporating black artists of different nationalities who display their art and black self-identity within the forum in various contexts. ${ }^{13}$

These religions circulate in Germany in different ways. Santeria was first brought in by migratory flows of Cubans in the 1970s, and a decade later Candomblé and Umbanda by Brazilians. According to Gruner-Domic ${ }^{14}$ and Rossbach de Olmos ${ }^{15}$ the "faith of the orixás" arrived in Germany in the 1970s, brought over by Cuban students and workers. The orixás' first stop was in communist Germany. Bilateral agreements between Cuba and the German Democratic Republic favored the arrival of Cuban professionals and workers in the 1970s. Many Cubans brought along their religious objects, especially when returning from vacation in Cuba, at a moment when German control over migration was less strict. Moreover, despite the limitations on expressing religion openly under a communist regime, the orixás could travel freely, through music and dance in particular. After reunification in the 1990s, a great number of Cubans remained in the country. Today, the reasons for the diffusion of Afro-Cuban Santeria ${ }^{16}$ have changed. In the last few years, according to Rossbach de Olmos ${ }^{17}$ mixed marriages, tourist trips to Cuba, and an increasing interest in Afro-Cuban music have led Germans to greater contact with African religions, triggering German interest in the Brazilian culture of Candomblé. ${ }^{18}$ Finally, their presence has been reinforced by Germans and Austrians who have specifically sought out these religions, either in Brazil or in the countries where Brazilian and Cuban pais and mães de santo circulate, inviting them into this universe.

I chose the Candomblé temple in Berlin as my first case study. Pai de santo Murah speaks fluent German and French. He worked as a butler in Brazil and survived by doing odd jobs while finishing his training as a dancer in São Paulo. Because of his family, his religion, and - later - his work engagements, Murah has lived in and between Bahia and São Paulo. He dances in Germany and travels around the world, working with different dance groups and in numerous Brazilian dance (salsa, samba and Afro-dance) ${ }^{19}$

${ }_{13}$ J. Bahia, Under the Berlin Sky ..., op. cit.; eadem, Dancing with the Orixás..., op. cit.

${ }_{14}$ S. Gruner-Domic, Die Migration Kubanischer Arbeitskräfte in die ddr 1978-1989, Berlin Humboldt-Universität (Magisterarbeit) 1996.

${ }^{15}$ L. Rossbach de Olmos, Santeria Abroad. The Short History of an Afro-Cuban Religion in Germany by Means of Biographies of Some of Its Priests, “Anthropos" 2009, no. 104, pp. 483-497.

${ }^{16}$ I do not study Santeria. I only wish to remark upon the fact that Cubans participated in the activities of the Ilê Obá Silekê, a Candomblé terreiro run by a Brazilian. The Brazilian father-of-saint Murah cooperates with the Afro-Cuban father of Saint Joaquim. They are long-time friends and collaborate in the local and European religious scene and in the sphere of dance, in which they work as professionals, carrying elements from both religions (Santeria and Candomblé) into the artistic sphere. Joaquim and his children-of-saints participate in Candomblé celebrations and rituals, including the parading of the Afoxé in the Carnival of Cultures in Berlin (see below). However, none of the Cubans I met had a terreiro in Germany, and many of Joaquim's children went to Cuba for their initiation rituals. Cuban and Brazilian sons- and daughters-of-saints from several temples and cults coming from different parts of Brazil and living in Germany and Europe have collaborated to ensure the maintenance and support of the Ilê in Berlin.

${ }^{17}$ L. Rossbach de Olmos, op. cit., pp. 484-485.

${ }_{18}$ See also J. Bahia, Under the Berlin Sky..., op. cit.

19 'Afro-dance' is the name given to a set of dances originating in African or African-American traditions, such as contemporary Afro-dance, Afro-jazz, and many popular rhythms (M. Rodríguez, Danzando lo Múltiple. Acerca de cómo Espejar a Reapropriación Religiosa y Artística de una Tradición de Matriz Africana, [in:] Cuerpos en Movimiento. Antropologia de y Desde las Danzas, S. Citro, P. Aschieri (eds.), 
and capoeira ${ }^{20}$ communities. He teaches African dance in the many cities and countries he visits and in his own terreiro. All these aspects highlight the importance of music and dance in the religious transnationalization of Candomblé. They are not only central parts of the life and work of Afro-Brazilian migrant artists, connecting art and religion: they constitute the modus operandi of Candomble transnationalization.

In the case of those who practice Candomblé, there are more divergences regarding these translations and to what degree making traditions sacred ${ }^{21}$ relates to the ways in which black identities have been constructed in different contexts in the diaspora. Movement is present in Candomble in many ways and is expressed in attitudes and bodily positioning such as in dance. In Candomblé, dance is an expression of man's eternal nature. It is a mirror of the cosmos that celebrates the continuity of all its components by bringing together the history of the orixás, their relationship to nature and the movements that relate them to the different parts of the body. These aspects awaken the senses of participants of the Afro-dance workshops to the idea of a body that dances not only to itself, but also for the gods. The heritage of African descendants, as witnessed in Berlin, is constantly reconfigured by dance and other art forms that make bodies move in public spaces such as workshops, Afoxés, and art exhibitions regarding the orixás. When one teaches Afro-dance, or how to sing songs that reference Candomblé, or how to cook for the gods, many aspects of the modus operandi of Candomblé are also taught. ${ }^{22}$

For some Brazilians the experience of practising Candomblé is a moment to revive memories of their black heritage or religious family. Many Brazilians initiated in the saint say that the religion allows for an individual expression of emotions and also makes them feel that they belong to a community or (better yet) a family of saint. ${ }^{23}$

For Germans and Europeans who seek out the Afro-Brazilians cults, the terreiro gains a new meaning. In Candomblé, the intertwining between the sacred and the

Buenos Aires 2012, pp. 238-239). It is part of a web of popular expressions that has been influenced by different manifestations of the numerous African diasporas. In the Afro-Brazilian cultural universe, capoeira, Candomblé, samba, jongo, lundu, Afoxé and other expressions are intertwined. Extending beyond physical movement, Afro-dance is also attuned to cultural and spiritual elements - especially with regards to the dances of the orixás. It also creates an experience that connects distinct perceptions of a wider African heritage that has influenced and been influenced by other rhythms (as in the case of samba in Brazil). This allows for cultural exchange between different fields. The dance of the orixás explores the movements associated with the orixás, their rhythms and songs. It is taught at workshops taking place after the rituals held at the terreiro studied here.

${ }^{20}$ Capoeira is an Afro-Brazilian martial art. It developed in Brazil among male slaves. After the abolition of slavery, it continued on in an urban context as a form of street fighting. Since the 1970s, capoeira has spread throughout the world and has been transforming accordingly (see e.g.: M.E. Domínguez, A. Frigério, Entre a Brasilidade e a Afro-brasilidade. Trabalhadores Culturais em Buenos Aires, [in:] Argentinos e Brasileiros. Encontros, Imagens e Estereótipos, A. Frigério, G.L. Ribeiro (eds.), Petrópolis 2002, pp. 41-70).

${ }^{21}$ B. Meyer, M. de Witte, Heritage and the Sacred. Introduction, "Material Religion" 2013, vol. 9 , no. 3 , p. 277.

22 J. Bahia, As Religiões Afro-brasileiras..., op. cit.

${ }^{23}$ Religious kindship within the cult group. Complex ritual genealogies link the initiate to different terreiros (temples) of the same axé (religious tradition transmitted via spiritual kin and also a force concentrated in objects and people). 
profane is embedded in the belief that the orixás are entities with powers, just like humans and gods. The orixás are not defined in an opposition of good and evil. The relationship of a person to his or her orixá connects him or her to nature because most orixás are related to forces of nature (wind, fire, water, and earth). Another idea Germans find appealing is the realisation that the power of nature is not only in nature, but it can be experienced through bodily practices. In Candomblé, the body is seen as becoming closer to nature and moving according to it. ${ }^{24}$

The Germans I met in the temple practice meditation, Buddhism and different New Age techniques, yet they believe there is a great power in Afro-Brazilian bodily practices that offers something beyond their previous spiritual experiences and brings them closer to Candomblé. Being in touch with and gaining some knowledge about musical experiences in the forum and the temple may signify spiritual gains for them.

However, I witnessed that especially in the case of Germans who start participating in the terreiro, possession becomes a point of departure from Candomblé. As some of them said, "Candomblé is not New Age," meaning that Candomblé is more religious than they thought it would be. They participated in the Candomblé rituals as a way to rethink themselves through orixás that represent the forces of nature. When their body becomes possessed, however, they come to realise that Candomble is more than a culture that valorizes the nature of African gods through dance and music, as the orixás appear to be "real" gods who are part of a religious hierarchy with many rules they need to obey. ${ }^{25} \mathrm{As}$ soon as they perceive that unlike their experiences with New Age and Buddhism, the spirituality of Candomble is more than meditation and self-reflection, and includes possession, animal sacrifices and obedience to the father- or mother-of-saint, most of them stop participating in the rituals of the terreiro. ${ }^{26}$

If, on the one hand, the physical well being promoted by new age therapies brings Europeans closer to the know-how of Afro-Brazilian religions, on the other hand, these same Europeans realise that they are involved with something greater than a simple spirituality and that they have to deal with religious hierarchical codes that they do not understand, and also with practices that take them out of their rational space of control of the body. Many thus abandon the religion.

Below, I present another case of how the religion expands, this one implying high mobility and different exchanges of material and spiritual things between clients and pais de santo. I explore how religion is being expanded in this case through the circulation of different magical practices of pais de santo and their clients, which mix Umbanda, Candomblé and oriental influences, thus creating new forms of hybridism. ${ }^{27}$ In these cases, there is a greater proximity between the New Age universe

${ }^{24}$ J. Bahia, Dancing with the Orixás..., op. cit.

${ }^{25}$ Ibidem.

${ }^{26}$ Cf. K. Hagedorn, "From This One Song Alone, I Consider Him to Be a Holy Man". Ecstatic Religion, Musical Affect, and the Global Consumer, "Journal for the Scientific Study of Religion" 2006, vol. 45 , no. 4 , p. 489.

27 A. Dirlik, The Post Colonial Aura. Third World Criticism in the Age of Global Capitalism, [in:] Dangerous Liaisons. Gender, Nation and Postcolonial Perspectives, McClintock et al. (eds.), Minneapolis 1997, pp. 501-528. 
already present in the European imaginary and the practices of Brazilian pais, who mix elements of Umbanda and Candomblé with Wicca and other knowledge that they acquire after moving to Europe.

\section{Beyond Germany: high mobility, mixture of religious practices and the circulation of things and people}

Most of the practices performed in the temple described above are related to Umbanda and Candomblé, but with different approaches and mixing different traditions. Many of the pais de santo interviewed, however, have knowledge of other magical traditions such as Wicca. ${ }^{28}$ They may have had reiki training or attgo to Santo Daime sessions. They might have had contact with oriental and Asian practices brought in by clients, as well as contact with other cultures which they have translated for individuals during consultations or even during their workshops in Germany. ${ }^{29}$

Most of the Brazilian pais de santo throw búzios (cowrie shells) ${ }^{30}$ and attend to clients independently in their houses, but not in temples. Their organisations constitute spiritual groups with a calendar and a given number of members (between 10 and 30 persons, including clients, filhos de santo and the pai or mãe de santo themselves). They do not become a casa de santo as it they would in Brazil, however. Most of the Brazilians I interviewed originally belonged to a Candomblé group in Brazil, but the majority prefer to pratice Umbanda because it has fewer rituals and rules than Candomblé (especially with regard to animal sacrifice).

Although most pais de santos start in Umbanda and come back to the pratices from the begining of their spiritual path, some pratices from Candomblé are retained. These include giving food to the orixá and singing and praying in Yoruba or other ritual languages. Some practicioners have a Lebensberatung license ${ }^{31}$ and also a license making them a legal entity. They use plants and herbs in baths, food, and healing and in the traditional blessings praticed in the areas of Brazil from which they came. They

${ }^{28}$ Religious practices that cultivate nature and which are supposedly rooted in ancient traditions of witchcraft, but which have been more recently adapted to urban everyday life.

${ }_{29}$ Through the life reform movement, German culture has maintained contact with various oriental and Asian cultures since the nineteenth century. This has facilitated the entry of Afro-Brazilian religions on the one hand, particularly those religions that promote a dialogue with the natural world (ideas that are present in the movement and which seek to promote an approximation between humans and nature). On the other hand, it brings pais and mães de santo into contact with a gamut of alternative practices that are easily available throughout German territory: reiki, Buddhist practices, meditation... Many of these practices are also present in the so-called Heilpraktiker movement). It also brings Afro-Brazilian religions closer to witchcraft and pagan culture in the German (and particularly the southern German) imagination. According to many of the Brazilians I have interviewed, it's not for nothing that a large number of German clients come from the southern region of the country. See: J. Bahia, Under the Berlin Sky ..., op. cit.; eadem, E o Preto Velho Fala Alemão..., op. cit., eadem, Dancing with the Orixás..., op. cit.

${ }^{30}$ Dilogun - or tossing the búzios - is a divination practice in Candomblé. The priest interprets messages from the gods by tossing 16 cowrie shells.

${ }^{31}$ See for example the case of Mutter Dalva, footnote 10, p. 152. 
mix popular Catholicism, indigenous pratices, and studies of Wicca and high magic knowledge into their practices.

The proximity of some pais de santo to Wicca facilitates comunication with Europeans, because they can practice simple rituals that are easier to understand and execute, such as healings and enchantments. The high magic rituals do not include many elaborate dishes, as do the Afro-Brazilian rituals. These take hours to prepare and often demand exotic ingredients bought at African or Asian markets. Neither does Wicca require as many food or sexual prohibitions as Umbanda and Candomblé do. In Candomblé especially, the body must be preserved from multiple interferences to maintain its sacredness and purity in order for healing magic to work and for people to connect with their orixás. In Candomblé, people eat together with their orixás or with their head orixá.

Henrique comes from Pará in the north of Brazil. He has always had clients from Germany, even when he lived in Brazil. Normally, his clients sent him objects they had used in Germany (that had long contact with their body or person) and Henrique used these to perform healing magic in Brazil. Henrique moved to Germany in 2003, maintaining his temple in Pará and his relationship with his own pai de santo. He perfoms some of his initiations in his temple in Brazil, sending clients and friends who need to be initiated to his pai de santo (Candomblé nagô, located in São Paulo). He does not want to develop the same sort of authorial relationship as is predicted in Candomble with his filhos de santo, especially the Europeans. These he prefers to teach, but not to maintain a "tense, complicated unnecessary respect for authority as most of the pais de santo in Brazil insist upon."

He does not limit his work to the German city where he lives. He has a network of clients in diferent cities throughout the country (Kiel, Rostock, Berlin, Freisburg, Postdam, Badenwutenberg, Munich and Stuttgart) and also in Portugal, ${ }^{32}$ France, Spain and the United Arab Emirates (UAE). ${ }^{33}$

Although the UAE does not allow any religions other than Islam, there are spirits in Muslim culture. These have the same role as the eguns in Candomblé: they are spirits of the dead and contact with them can be very dangerous. These spirits are not easily seen and people have to protect themselves from them. The proximity of Muslims to African cultures means that they understand the uses of food, animals, and cereals in cleansing their bodies of the malignant influence of these spirits. These eguns have an Arabic name: Djinn or Jinn. These translations are made by Henrique together with his Muslim clients. The time and space of the workshop and the

32 He worked for a group of shops in Lisbon and earned much money and prestige. However, Henrique preferred to establish himself in Germany and expand his client base there. According to Henrique, his orixá Obaluaiê brought him much prestige, but his services could only be divulged through people and he was spiritually prohibited from using the internet or advertising his services. Even religious markets are permeated with magic, and mercantile logic may often be subordinate to the demands of magical logic.

${ }^{33}$ During Henrique's workshop in Dubai, all the women clients wear white jihabs and learn to cook the votive foods used in Umbanda and Candomblé to make the ebós (positive magic work, offerings for the orixás). In Dubai, his ritual objects were seized at the airport and he was fined 1,700 dollars. Henrique has been an initiate for more than 20 years, however, and he did not pay the fine, preferring to reconstruct all the objects. 
individual consultations are also propitious for making translations between different religions, which can be approximated or adapted during spiritual work. Both the eguns and the jinni are variable. Some may trouble your marriage, others your sexual behaviour or your path in general. In any case, they need to be removed from your life. He has worked in 19 countries and considers himself to be a "portable or delivery father of saint," spreading the religion to different places.

Being a "delivery pai de santo" means being able to translate the feelings and difficulties of one's clients within several different cultural environments, as well as moving between different spiritual scenarios. It also demands that one remembers that spirituality is something which can migrate and which can be accessible as a train trip (a metaphor used by Henrique himself). In this sense, "delivering the religion" is important, but one cannot deliver it as traditionally practiced. Rather, one packages it as "spirituality," which is something that is more understandable to the clients in question.

In this sense, New Age language also becomes something more familiar to clients. With regards to this correlation, in Portugal there are stores that offer Afro-Brazilian religious services in a discreet way, where the entrance of the store highlights oriental or even more esoteric logic and symbols. ${ }^{34}$ Many pais de santo in Portugal run a store while at the same time attending to and consulting with clients. Their stores sell things that are not just related to Candomblé, however, they attend to a broader market that covers multiple forms of religious knowledge..$^{35}$ In a case I studied in Évora, a store's advertising flyer refers to itself as not just a place where "amulets, medicinal herbs, confection of ritual clothes" are sold, but also a place where one can gain knowledge about "the mystery of African orixás." The store is thus linked to the terreiro and its operation: one thing logically leads to another. This practice is common and found throughout Portugal, as Guillot ${ }^{36}$ initially demonstrated. It is an artefact of the relationship between the "religious supermarket" and the various religions qualified as "New Age." In this sense, then, commercial logic becomes mixed with other symbolic logics, translating "religious commerce" into the terms of the other religious practices that are also part of the clients' lives. If clients move from faith to faith, so do the religious objects in the stores in order to better attract diverse types of clients, and not only those interested in Afro-Brazilian religions.

This also brings us to the question of mercantile logic. Even though a pai de santo may announce that a given client can become a medium, they need to develop their abilities as such; many if not most clients are just looking for a way to ease their troubles - be these job-related, financial, sexual, etc. - and do not really want to go beyond having the pai or mãe throw the búzios. Consultations are part of the religious market in which Brazilian efficiency is understood to be powerful and imbued with

${ }^{34}$ M. Guillot, N.J. Huet, Dinámicas Religiosas y Lógica Mercantil de las Religiones Afroamericanas en México y Portugal, [in:] En Sentido Contrario. Transnacionalización de Religiones Africanas y Latinoamericanas, K. Argyriadis, S. Capone, R. de la Torre, A. Mary (eds.), Ciesas 2012, pp. 63-84; J. Bahia, E o Preto Velho Fala Alemão..., op. cit.

35 J. Bahia, E o Preto Velho Fala Alemão..., op. cit., p. 181.

${ }^{36}$ M. Guillot, N.J. Huet, op. cit., p. 80. 
a special form of knowledge. For example, Henrique lives in a very wealthy city and has many clients who are stockbrokers. These people generally want information about the business world. For other clients, spirituality becomes thought of as part of their problems, going beyond a mere toss of the búzios, pushing them towards new paths they had not yet thought of.

On the other hand, many of the Brazilian pais de santo I interviewed believe that Brazilian spiritual know-how is indeed one of the most complete in the world and that this knowledge does in fact come from Brazil and can indeed be accessed by everyone, depending on a given person's willingness or ability to dive deeply into it. It is also worth remembering here that being a pai de santo involves incorporating functions that demand years of study in Germany: Heilpraktiker and the Jäger. ${ }^{37} \mathrm{In}$ other words, being a Brazilian pai de santo is a mixture of knowing alternative and traditional medical practices (homeopathy, acupuncture, crystal therapy, reiki, etc.) and the accumalated wisdom of the hunter, with the advantage that these techniques are often learned while the future pai or mãe is still a child ${ }^{38}$ in Brazil. Furthermore, these Brazilians are often the bearers of knowledge that is coded in Yoruba or other African languages, which are used in rituals that involve animals and plants. ${ }^{39}$

Some of the people I have interviewed have shown how these years of accumulated knowledge can become mobile and applied in different contexts, even in contacts with the Islamic world, whose spiritual categories can also be translated into those of the African diaspora.

For example, Caetano normally stays two months a year in Dubai. In this country, he begins his work with a workshop about the energy of the orixás and explains what his spiritual work consists of. Each person pays a fee to listen to him talk. The ones who are interested in his work receive consultations with búzios and tarot cards. He also prepares cleansing formulas for their bodies. In Quatar, Caetano works to bring money to his clients, opening up ways for their prosperity. He is assisted in this by a local capoeira teacher who is also a kind of shaman.

${ }^{37}$ I am not affirming that there are no limits to or problems with this transnationalization. Sacrifice is one of these, given that it is prohibited by German law and killing animals in this fashion is only possible for those who have a hunting license. Herb use must also follow the Heilpraktiker codes, which limits the enormous amount of knowledge of herbal baths, infusions, and food herbs contained in Afro-Brazilian religions.

${ }^{38}$ In general, children can be initiated in both Candomblé and Umbanda. They have an important role in learning the faiths's beliefs (S. Caputo, Educação nos Terreiros. E como a Escola se Relaciona com Crianças de Candomblé, Rio de Janeiro 2012).

${ }^{39}$ In Yoruba, however, animals are related to orixás and have special treatment. In sacrifices, they are literally transformed into gods. I am not saying though that animal sacrifices play a role in the quotidian practices of these pais and mães de santo: I merely wish to point out how this "know-how" is valued in the religious market. The Europeans seem to imagine that in "voodoo" (a term used to simplify the vast gamut of African religions), Brazilian "know-how" is preferential. This appears in the use of Portuguese in Umbanda rituals performed by Germans and Austrians and in the reluctance to translate certain texts and words, out of a fear that this could make certain relationships less legitimate in the religious field (J. Bahia, E o Preto Velho Fala Alemão..., op. cit.). In this sense, language is a precious resource that maintains legitimacy. The fact that many German and European pais and mães de santo do not throw búzios or engage in other divinatory practices pushes many of their filhos de santo to seek out Brazilian priests, increasing competition between native born and foreign religious leaders, as I have observed in my fieldwork. 
The transnationalization process shows how portable practices are, and how easily messages can be translated into rituals that foreign clients can comprehend, even though these have limited knowledge of magic. ${ }^{40}$ This expansion/translation of ritual is a negotiation between clients, the pai de santo and their cultural and spiritual dispositions to extend beyond the borders of their knowledge. These transitions are also physcial and may involve a client travelling to Brazil to be initiated, learning to pray and to cook, reading books on Afro-Brazilian religious themes, or even becoming a member of the pai de santo's small ritual group. One day, one might even be initiated into the mysteries of the orós (the secrets of the religion), but it is a long climb.

This proliferation of multidirectional and multi-scaled flows that both exit and enter Brazil is present in the daily lives of the social actors who comprise these religions. ${ }^{41}$ Faced with easy geographical mobility, many pais de santo move their practices into different countries and cultures, as they themselves move their persons and cult objects, making sacred different traditional heritages ${ }^{42}$ with the inclusion of new mixtures. Many of the objects in Henrique's house come from the different countries where he works, while some are presents from clients, friends, or filhos de santo. He has a small wooden statue of Oxum brought from Nigeria by his Portuguese filha de santo, who travels frequently to that country. But Henrique's most interesting possession is his Naja (a kind of snake) perfume, bought during one of his travels, which he mixes with the herbs and magical essences of Pará to transform someone to look like a Naja: a mediator of the worlds of gods and men in the asiatic culture. ${ }^{43}$ In this sense, objects are transformed. Objects such as the enchanted aromas of the Ver-o-peso market in Pará are mixed with the Egyptian Naja in a spell made by the pai de santo to appeal to all his customers who wish to be so seen by others. The snake enchants more when the Brazilian herbs are added to it, paralysing others who seek those who use the charm. The pais de santo thus hark back to the old alchemists of the European world, with their chemistry transmuted by Brazil.

André, another pai de santo I interviewed, moved his establishment from Berlin to Hamburg - not because this would provide him with good clients (which is true), but also because it was easier to find natural spaces in Hamburg. Berlin is considered by many to be too urban for the practice of Candomblé. There is a large Portuguese community in Hamburg which migrated in the 1950s to Germany and many of André's best clients come from this community. André travels extensively, attending to people from different parts of Germany, and he has a Gewerbereise which means that his Lebenberatung allows him to work while travelling, healing people in different places. During André's consultations and workshops, he explains what this sort of spirituality is to Germans, who initially believe adivination to be something

40 T. Csordas, Transnational Transcendence. Essays on Religion and Globalization, Berkeley 2009.

${ }^{41}$ C. Rocha, M. Vásquéz, The Diaspora of Brazilian Religions, Boston 2013; J. Bahia, E o Preto Velho Fala Alemão..., op. cit., pp. 181-212.

${ }^{42}$ B. Meyer, M. de Witte, op. cit.

${ }^{43}$ There is an equivalent in Yoruba culture: Oxumaré. This god is represented by a rainbow and also by a snake, the symbol of prosperity and duplicity. This orixá is the mediator of two worlds: Olorum and Aiyê. 
well-known and kind of archaic, especially in southern Germany and Austria. These Germans are then given their introduction to the búzios.

According to André, his clients have no idea what the orixás are, either in general or specifically. He explains how he makes himself intelligible to these Europeans: "For some Europeans, it's a question of what energy a saint is made of. So I'll explain to a German that there is a spirit that appears when we throw the buizios, that she is the goddes of the waters and also of love, that she will protect you if you enter into harmony with her. The name of this goddess is Oxum and you can look her up on the Internet." When it comes to Portuguese clients, however, these want to know which Catholic saint is related to which orixá.

Thus, the consultation of cowrie shells is translated and negotiated according to the possibilities and exchanges of information between the pai de santo and the client. With many clients the pai de santo restricts himself to talking about the questions asked, but with others the magician insinuates himself in other ways. Both André and Henrique, as well as other Brazilians I interviewed, consider it to be a victory when a European apprentice allows their body to be used by their spirit. This is especially true in Germany, which they consider to be an extremely skeptical country. In spite of this skepticism, however, they point out that European history is filled with witches, magic, and enchantments. In other words, the apprenticeship gives people a certain disposition for magic and can revive lost knowledge that is in everyone's family history.

As an example, a German of Hungarian origins took up the old tarot tradition that his grandmother had taught him as a child. This memory was renewed within him when he was possessed and it brought with it other stories, moments, and characters from his personal history. He is now a son of Xangô (the god of fire). In his first possession, he felt ants walking all over his body and did not know what to do. The orixá took control of his body and he lost consciousness. A bori frio ${ }^{44}$ was thus conducted, with food being given to his orixás. This calmed Xangô. The man now has a small altar to his gods in his home in Bodensee.

All these experiences are translated into different languages, connecting people and spiritis to new senses of places and body sensations, producing thoughts, writings and new constructions of belonging to different worlds. ${ }^{45}$ The son of Xangô starts to materialize all these conections into an altar, a new home for his orisha and new interpretations for his own personal history with his main orisha (the owner of his head).

\section{Conclusion}

The bodily practices of Candomble betray some similarities to those found in the German New Age universe. At first, this contributes to the positive reception of Afro-Brazilian religions in Germany by acknowledging the power of the body within

${ }^{44}$ It is a ritual that you give food to the head (ori), in this case it was a cold bori which means that it was oferred only food.

${ }^{45}$ A. Appadurai, A Vida Social das Coisas. As Mercadorias sob uma Perspectiva Cultural, Rio de Janeiro 2008. 
a different modus operandi. Limits arise, however, when the gods who bring many followers to Candomblé are also the orixás who make their filhos de santo fall and feel pain whenever they are not controlled by a trance, transforming the body into something unknown. Only a trance (after religious initiation) can restore the relationship between men, their gods, and the body.

On the one hand Candomblé connects the African heritages that have been constructed in various contexts in the diaspora, but on the other it brings different European public from New Age practises who values the body and its sensations as a knowledge about themselves. However, the language, rituals and the difficulties in translation are not the same as the fathers of saints who bring the interconnection between Umbanda and many various kinds of practises related to the mainstream of the New Age rituals, which are much more common in Europe.

Unlike the practices of the terreiro I am analysing here (Ilê Obá Silekê) and the connection of religion with the artistic world, there are many pais de santo who give consultations and do work without having a fixed ritual space. These do not conduct initiations and do not create new filhos de santo, as is the case in the more traditional hierarchy of Candomble terreiros. Many of these fathers of saints easily employ New Age practices, mixing these together with those of Umbanda and Candomblé. By incorporating Wicca, Santo Daime, and other therapies, they more easily approximate themselves to the religious values of their European clients. Consequently, other objects brought by clients are incorporated into the daily life of these pais de santo, as in the example of the cobra spell given above.

The cases of the fathers of saints who considered themselves "delivery" are interesting in understanding not only the circulations of things, people and traditions in new readings but also the translations of these practises.

The multiplicity of translations and exchanges in Umbanda and Candomblé presented in the cases above show how the exchanges between practices, materials, and spirituals between clients, the families of saints and their mothers and fathers of saints can transform the transnational religious field more complex as it is.

\section{References}

Appadurai A., A Vida Social das Coisas. As Mercadorias sob uma Perspectiva Cultural, Rio de Janeiro 2008.

Bahia J., As Religiões Afro-brasileiras em Terras Alemãs e Suiças, http://www.ics.ul.pt/publicacoes/workingpapers/wp2013/wp2013_1.pdf [access: 17.01.2019].

Bahia J., Dancing with the Orixás. Music, Body and the Circulation of African Candomble Symbols in Germany, "African Diaspora" 2016, no 9, pp. 15-38.

Bahia J., E o Preto Velho Fala Alemão. Espíritos Transnacionais e o Campo Religioso na Alemanha, "Revista del Cesla" 2015, no. 18, pp. 181-212.

Bahia J., Umbanda, [in:] Encyclopedia of Latin American Religions, H. Gooren (ed.), [in print].

Bahia J., Under the Berlin Sky. Candomblé on German Shores, "Vibrant. Virtual Brazilian Anthropology" 2014, vol. 11, p. 2, pp. 327-370. 
Behrends J., Fremde und Fremd-Sein in der DDR. Zu historischen Ursachen der Fremdenfeindlichkeit in Ostdeutschland, Berlin 2003.

Brubaker R., Citizenship and Nationhood in France and Germany, New York 1990.

Capone S., A Busca da África no Candomblé. Tradição e Poder no Brasil, Rio de Janeiro 2009.

Caputo S., Educação nos Terreiros. E como a Escola se Relaciona com Crianças de Candomblé, Rio de Janeiro 2012.

Csordas T., Transnational Transcendence. Essays on Religion and Globalization, Berkeley 2009.

Dirlik A., The Post Colonial Aura. Third World Criticism in the Age of Global Capitalism, [in:] Dangerous Liaisons. Gender, Nation and Postcolonial Perspectives, McClintock et al. (eds.), Minneapolis 1997, pp. 501-528.

Domínguez M.E., Frigério A., Entre a Brasilidade e a Afro-brasilidade. Trabalhadores Culturais em Buenos Aires, [in:] Argentinos e Brasileiros. Encontros, Imagens e Estereótipos, A. Frigério, G.L. Ribeiro (eds.), Petrópolis 2002, pp. 41-70.

Gilroy P., O Atlântico Negro, São Paulo 2001.

Gruner-Domic S., Die Migration Kubanischer Arbeitskräfte in die ddr 1978-1989, Berlin Humboldt-Universität (Magisterarbeit) 1996.

Guillot M., Huet N.J., Dinámicas Religiosas y Lógica Mercantil de las Religiones Afroamericanas en México y Portugal, [in:] En Sentido Contrario. Transnacionalización de Religiones Africanas y Latinoamericanas, K. Argyriadis, S. Capone, R. de la Torre, A. Mary (eds.), Ciesas 2012, pp. 63-84.

Hagedorn K., "From This One Song Alone, I Consider Him to Be a Holy Man”. Ecstatic Religion, Musical Affect, and the Global Consumer, "Journal for the Scientific Study of Religion" 2006, vol. 45, no. 4, pp. 489-496.

Lidola M., Appropriating the "Brasilienerin". Negociating Belonging and Unbelonging in Everyday Practice in Berlin, "Zeitschrift für Ethnologie" 2011, no. 136, pp. 379-400.

Marcus G., Ethnography in/of the World System. The Emergence of Multisited Ethnography, "The Annual Review of Anthropology" 1995, no. 24, pp. 95-117.

Matory J., Jeje. Repensando Nações e Transnacionalismo, "Mana. Estudos de Antropologia Social" 1999, vol. 5, no. 1, pp. 57-80.

Meyer B., Witte M. de, Heritage and the Sacred. Introduction, "Material Religion" 2013, vol. 9, no. 3, pp. 274-280.

Nagl D., Grenzfälle: Staatangehörigkeit, Rassismus und nationale Identität unter deustcher Kolonialherrschaft, Frankfurt a.M. 2007.

Port Van M. de, Candomble in Pink, Green and Black. Rescripting the Afro-Brazilian Religious Heritage in the Public Sphere of Salvador, Bahia, "Social Anthropology" 2005, vol. 13, no. 1, pp. 3-26.

Port Van M. de, "Don't Ask Questions, Just Observe!". Boundary Politics in Bahian Candomblé, [in:] Aesthetic Formations. Media, Religion, and the Senses in the Making of Communities, B. Meyer (ed.), Basingstoke, NY 2009, pp. 31-51.

Rocha C., Vásquéz M., The Diaspora of Brazilian Religions, Boston 2013.

Rodríguez M., Danzando lo Múltiple. Acerca de cómo Espejar a Reapropriación Religiosa y Artística de una Tradición de Matriz Africana, [in:] Cuerpos en Movimiento. Antropologia de y Desde las Danzas, S. Citro, P. Aschieri (eds.), Buenos Aires 2012, pp. 233-252.

Rossbach de Olmos L., Santeria Abroad. The Short History of an Afro-Cuban Religion in Germany by Means of Biographies of Some of Its Priests, “Anthropos" 2009, no. 104, pp. 483-497.

Souza E., Ekodidé. Relações de Gênero no Contexto dos Afoxés de Culto Nagô no Recife, Masters Dissertation, Post-graduate Program in Anthropology Federal University of Pernambuco, Recife 2010. 